\title{
Notch signaling in mouse blastocyst development and hatching
}

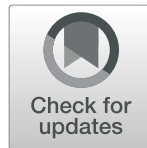

Mariana R. Batista ${ }^{1}$, Patrícia Diniz ${ }^{1}$, Ana Torres ${ }^{1}$, Daniel Murta ${ }^{1,2}$, Luís Lopes-da-Costa ${ }^{1 *}$ (D) and Elisabete Silva ${ }^{1}$

\begin{abstract}
Background: Mammalian early embryo development requires a well-orchestrated interplay of cell signaling pathways. Notch is a major regulatory pathway involved in cell-fate determination in embryonic and adult scenarios. However, the role of Notch in embryonic pre-implantation development is controversial. In particular, Notch role on blastocyst development and hatching remains elusive, and a complete picture of the transcription and expression patterns of Notch components during this time-period is not available.

Results: This study provided a comprehensive view on the dynamics of individual embryo gene transcription and protein expression patterns of Notch components (receptors Notch1-4; ligands DII1 and DII4, Jagged1-2; and effectors Hes1-2), and their relationship with transcription of gene markers of pluripotency and differentiation (Sox2, Oct4, Klf4, Cdx2) during mouse blastocyst development and hatching. Transcription of Notch1-2, Jagged1-2 and Hes 1 was highly prevalent and dynamic along stages of development, whereas transcription of Notch3-4, DI/4 and Hes2 had a low prevalence among embryos. Transcription levels of Notch1, Notch2, Jagged2 and Hes 1 correlated with each other and with those of pluripotency and differentiation genes. Gene transcription was associated to protein expression, except for Jagged2, where high transcription levels in all embryos were not translated into protein. Presence of Notch signaling activity was confirmed through nuclear NICD and Hes1 detection, and downregulation of Hes 1 transcription following canonical signaling blockade with DAPT. In vitro embryo culture supplementation with Jagged1 had no effect on embryo developmental kinetics. In contrast, supplementation with Jagged2 abolished Jagged 1 transcription, downregulated Cdx2 transcription and inhibited blastocyst hatching. Notch signaling blockade by DAPT downregulated transcription of Sox2, and retarded embryo hatching.

Conclusion: Transcription of Notch genes showed a dynamic pattern along blastocyst development and hatching. Data confirmed Notch signaling activity, and lead to the suggestion that Notch canonical signaling may be operating through Notch1, Notch3, Jagged1 and Hes1. Embryo culture supplementation with Jagged1 and Jagged2 unveiled a possible regulatory effect between Jagged1, Cdx2 and blastocyst hatching. Overall, results indicate that a deregulation in Notch signaling, either by its over or under-activation, affects blastocyst development and hatching.
\end{abstract}

Keywords: Blastocyst, Development, Hatching, Notch, Mouse

\footnotetext{
* Correspondence: Icosta@fmv.ulisboa.pt

${ }^{1}$ Reproduction and Development Laboratory, CIISA - Centro de Investigação

Interdisciplinar em Sanidade Animal, Faculdade de Medicina Veterinária,

Universidade de Lisboa, 1300-477 Lisbon, Portugal

Full list of author information is available at the end of the article
}

(c) The Author(s). 2020 Open Access This article is licensed under a Creative Commons Attribution 4.0 International License, which permits use, sharing, adaptation, distribution and reproduction in any medium or format, as long as you give appropriate credit to the original author(s) and the source, provide a link to the Creative Commons licence, and indicate if changes were made. The images or other third party material in this article are included in the article's Creative Commons licence, unless indicated otherwise in a credit line to the material. If material is not included in the article's Creative Commons licence and your intended use is not permitted by statutory regulation or exceeds the permitted use, you will need to obtain permission directly from the copyright holder. To view a copy of this licence, visit http://creativecommons.org/licenses/by/4.0/ The Creative Commons Public Domain Dedication waiver (http://creativecommons.org/publicdomain/zero/1.0/) applies to the data made available in this article, unless otherwise stated in a credit line to the data. 


\section{Background}

Abnormal mammalian preimplantation embryo development is responsible for a significant prevalence of embryo-fetal mortality in both human and domestic animal species [1, 2]. However, the complex spatial and temporal orchestration of cellular events associated with early development, which require a finely tuned intercellular communication, is still largely unresolved. Zygote cleavage leads to the compact morula stage, where the first cellular differentiation events originate the blastocyst [3]. The blastocyst comprises two cell types: i) trophectoderm (TE) - which will give rise to the placenta, and ii) inner-cell-mass (ICM) - which will constitute the embryo itself [4]. The maintenance of TE epithelial integrity and differentiated status relies on transcription factor $\mathrm{Cdx} 2$ expression $[5,6]$. Likewise, ICM pluripotency maintenance relies on expression of a wide network of transcription factors, namely Sox2, Oct4 and Klf4 [7, 8].

Several cell signaling pathways critical for embryo development have been identified in the mouse preimplantation embryo [9]. The Notch cell signaling pathway, highly conserved among invertebrates and vertebrates, has been implicated as a main regulator of cellular differentiation and proliferation in many adult and embryonic scenarios [10-13], and was identified in several mammalian preimplantation embryos, including the mouse [14-19]. In mammals, Notch is a receptor-ligand based cell signaling pathway composed of four receptors (Notch1-4) and five ligands (Delta-like (Dll) 1, 3 and 4; Jagged1 and 2). Notch signaling may be conveyed in the so-called canonical and non-canonical forms, reflecting a high mechanistic complexity, yet to be fully understood (for reviews see [20-22]). Briefly, the canonical signaling results from the interaction of a ligand expressed by the signal-sending cell with a transmembrane receptor expressed by a signal-receiving neighboring cell. This binding of the ligand in trans leads to the sequential cleavage of the intracellular domain (NICD) of the receptor by extracellular ADAM proteases and an intracellular $\gamma$-secretase, and its translocation to the nucleus. Here, NICD de-represses the transcription complex $\mathrm{Rbpj}$, to regulate the transcription of Notch effector genes (including Hes1 and Hes2). Signal termination is ensured by ubiquitin-dependent proteasome degradation of NICD. Knowledge on non-canonical Notch signaling in mammalian systems is still largely fragmentary [22]. This form is ligand independent and/or does not require NICD interaction with Rbpj [23]. The role of Notch signaling in embryo preimplantation development is controversial. Earlier studies reported that canonical Notch signaling is not required for early embryo development $[24,25]$, although subsequent studies showed that pharmacological inhibition of the pathway with DAPT (a $\gamma$-secretase inhibitor) affects embryo implantation [26]. More recently, studies using mutant knockout embryos unveiled a role for Notch, together with the Hippo pathway, on TE lineage assignment [13, 27, 28].

This study considered the evaluation of Notch signaling, in individual embryos, in a defined time-frame of mouse preimplantation embryonic development blastocyst differentiation from compact morulae until blastocyst hatching. This evaluation included gene transcription (quantitative real-time PCR; qRT-PCR), protein expression (immunocytochemistry; ICC), and in vitro embryo culture supplementation with Notch activators and inhibitors. In transcription analysis, the first step was to identify the prevalence of transcription of Notch (receptors, ligands and effectors) and pluripotency and differentiation genes along four developmental stages: compact morulae $(\mathrm{CM})$, blastocyst $(\mathrm{BL})$, expanded blastocyst (EBL) and hatched blastocyst (HBL). The second step was to evaluate the levels of transcription of each gene at each developmental stage. The above data allowed the evaluation of transcription relationships (correlations) between Notch and pluripotency and differentiation genes. Evaluation of protein expression by ICC at the BL stage evidenced mRNA translation and the nuclear identification of NICD and/or effectors, thus confirming Notch signaling activity. Finally, in vitro embryo culture with a $\gamma$-secretase (Notch signaling blockade) or with Notch ligands (putative activators) evidenced phenotypic effects in embryo development and gene transcription. Therefore, the objectives of this study were, at the individual embryo level, to evaluate i) the signaling status of Notch pathway and the dynamic patterns of transcription and expression of Notch components, from the compact morulae stage until blastocyst hatching; ii) the relationship between the transcription of Notch components and gene markers of embryonic pluripotency and differentiation; and iii) the effects of supplementation with Notch ligands and Notch signaling inhibitors on blastocyst development and hatching.

\section{Results}

\section{Gene transcription}

Transcription prevalence and levels of Notch and pluripotency and differentiation genes was analyzed by qRTPCR in individual embryos at four developmental stages: 3.5 days post-coitum (dpc) CM, BL and EBL, and $4.5 \mathrm{dpc}$ HBL. Based on RNA-seq databases [18, 19], $\operatorname{Lgr} 5$ was chosen as negative gene transcription control, as this pluripotency-associated gene showed very low transcription levels in embryonic cells of developmental stages considered in this study. Table 1 shows gene transcription prevalence among individual embryos and stages of development, and Fig. 1 illustrates the respective agarose 
Table 1 Prevalence of gene transcription among embryos at each stage of development

\begin{tabular}{|c|c|c|c|c|}
\hline \multirow[t]{2}{*}{ Gene } & \multicolumn{4}{|c|}{ Stage of development } \\
\hline & $\mathrm{CM}$ & $\mathrm{BL}$ & $\mathrm{EBL}$ & $\mathrm{HBL}$ \\
\hline Notch1 & $9 / 9$ & $9 / 9$ & $7 / 7$ & $5 / 5$ \\
\hline Notch2 & $9 / 9$ & $9 / 9$ & $7 / 7$ & $5 / 5$ \\
\hline Notch3 & $5 / 9$ & $3 / 9$ & $0 / 7$ & $2 / 5$ \\
\hline Notch4 & $0 / 9$ & $0 / 9$ & $1 / 7$ & $2 / 5$ \\
\hline DII1 & $0 / 9$ & $0 / 9$ & $0 / 7$ & $0 / 5$ \\
\hline D//4 & $0 / 9$ & $0 / 9$ & $2 / 7$ & $1 / 5$ \\
\hline Jagged 1 & $6 / 9$ & $9 / 9$ & $7 / 7$ & $4 / 5$ \\
\hline Jagged2 & $9 / 9$ & $9 / 9$ & $7 / 7$ & $5 / 5$ \\
\hline Hes 1 & $9 / 9$ & $9 / 9$ & $7 / 7$ & $5 / 5$ \\
\hline Hes2 & $5 / 9$ & $3 / 9$ & $3 / 7$ & $0 / 5$ \\
\hline $\operatorname{Lgr} 5$ & $0 / 9$ & $0 / 9$ & $0 / 7$ & $0 / 5$ \\
\hline Sox2 & $9 / 9$ & $9 / 9$ & $7 / 7$ & $5 / 5$ \\
\hline KIf4 & $9 / 9$ & $9 / 9$ & $7 / 7$ & $5 / 5$ \\
\hline$C d \times 2$ & $9 / 9$ & $9 / 9$ & $7 / 7$ & $5 / 5$ \\
\hline Oct4 & $9 / 9$ & $9 / 9$ & $7 / 7$ & $5 / 5$ \\
\hline
\end{tabular}

Prevalence is depicted as the number of embryos with specific amplification of the gene in relation to the total number of embryos analyzed. CM Compact Morulae, BL Blastocyst, EBL Expanded Blastocyst, $H B L$ Hatched Blastocyst

gels of qRT-PCR products (displaying four embryos / gene / stage of development). Regarding Notch genes, transcription of receptors Notch1 and Notch2, ligand Jagged 2 and effector Hes 1 was detected in all embryos, and transcription of ligand Jagged 1 was detected in all but four embryos. Receptors Notch3 and Notch4, ligand Dll4 and effector Hes2 had inconsistent transcription among embryos, whereas transcription of ligand Dll1 was not detected. Transcription of pluripotency and differentiation genes (Sox2, Oct4, Klf4, Cdx2) was detected in all embryos, whereas transcription of negative control Lgr5 was not detected.

Figure 2 panel a, shows the mean transcription levels of Notch and pluripotency and differentiation genes at each developmental stage (values are presented as the $\log _{2}$ of power of $\Delta \Delta \mathrm{Ct}$ values). Only genes with consistent transcription among embryos were considered in this analysis. Figure 2 panel $\mathrm{b}$ shows the fold change values of transcription levels of Rps29 and Hprt1 control endogenous (housekeeping) genes at each developmental stage. The transcription levels of target genes at the $\mathrm{BL}$, EBL and HBL stages were then compared to those at the CM stage (values are presented as the $\log _{2}$ of power of $\Delta \Delta \mathrm{Ct}$ values, with $\mathrm{CM}$ stage as calibrator) (Fig. 2 panel c). Based on above results, the dynamics of gene transcription along developmental stages is schematically illustrated in Fig. 3. As depicted from these figures, transcription of Sox2, Oct4, Klf4, Cdx2, Notch1, Notch2 and Jagged 2 increased throughout development, mainly at the HBL stage, whereas transcription of Jagged 1 and Hes1 remained fairly constant.

Transcription levels of Notch1, Notch2, Jagged2 and Hes 1 correlated with those of all pluripotency and differentiation genes $(r=0.72$ to $0.95, p=0.004$ to $p<0.0001)$. Notch1 correlated with Notch2, Jagged2 and Hes1 $(r=$ 0.75 to $0.86, p<0.0001)$, Notch 2 correlated with Jagged 2 and Hes1 $(r=0.79$ and $0.72, p<0.0001$ and $p=0.001$, respectively), and Jagged 2 correlated with Hes1 $(r=0.78$, $p<0.0001)$.

\section{Gene expression}

Since the BL represents the earliest developmental stage in which the two initial cell lineages - ICM and TE are segregated and have reached their final spatial location, this embryonic stage was chosen to evaluate the presence of Notch proteins. As shown in Fig. 4a, Notch1-4 were expressed in BL, and Notch1 and Notch3 were detected in the nucleus of presumptive TE cells. This indicates that the receptors were cleaved and NICD was translocated into the nucleus, thus confirming Notch signaling activation through these receptors. Ligands Dll4 and Jagged1 were expressed in BL, whereas ligands Dll1 and Jagged2 were not detected (Fig. 4c). Effector Hes1 was detected in the nucleus of some cells, whereas Hes 2 only showed a diffuse pattern in the cytoplasm (Fig. 4b).

\section{Notch signaling activation or blockade in cultured embryos}

To further confirm Notch activity in mouse early embryonic development, Notch signaling was inhibited through a pharmacological approach with DAPT $(\mathrm{N}-[\mathrm{N}-$ (3,5-Difluorophenacetyl)-L-alanyl]-S-phenylglycine tbutyl ester), a $\gamma$-secretase inhibitor which prevents the intracellular cleavage of NICD and its translocation to the nucleus. Together with embryo culture supplementation with recombinant Jagged1 and Jagged2 (putative Notch activators), this experiment allowed the observation of effects of Notch signaling inhibition or activation on blastocyst development and hatching. As shown in Table 2, DAPT, Jagged1 and Jagged2 treatments had no effect on embryo viability, as depicted from the number of non-degenerated morphologically normal embryos progressing in culture. However, embryo kinetics was affected by DAPT treatment, which decreased the early hatching blastocyst rate at $4.0 \mathrm{dpc}(p<0.05)$, and the hatched blastocyst rate at $4.5 \mathrm{dpc}$ (statistical tendency, $p=0.12$ ) (Fig. 5b-c). At $4.0 \mathrm{dpc}$, both Jagged1 and Jagged2 treatments prevented the progression of $\mathrm{CM}$ (Fig. 5b), whereas at $4.5 \mathrm{dpc}$ Jagged2 supplementation significantly inhibited blastocyst hatching (Fig. 5c).

To evaluate the possible relationship between the above changes in developmental kinetics and gene 

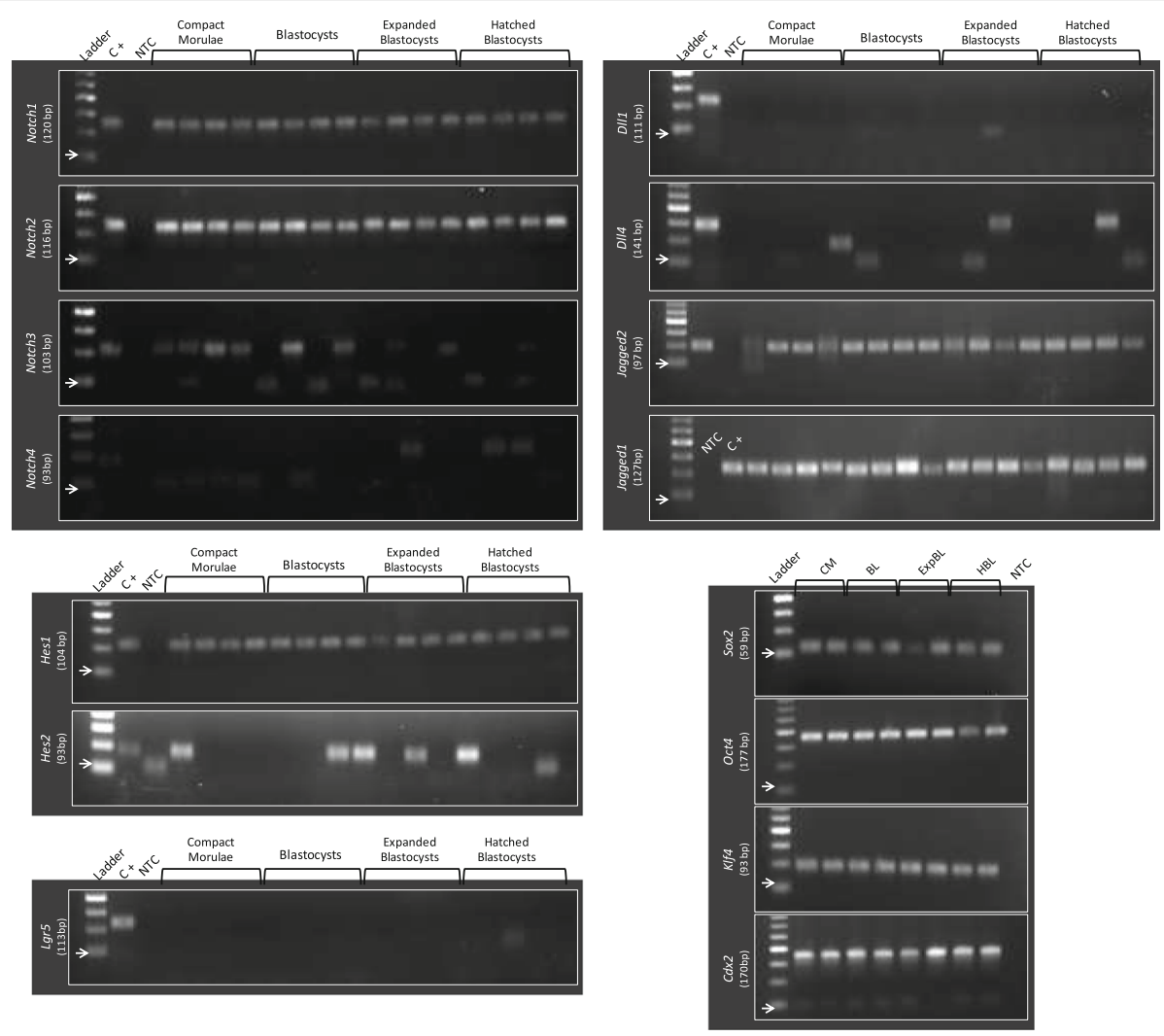

Fig. 1 Agarose gels of qRT-PCR products. For each Notch component gene (receptors, ligands and effectors; plus negative control), four representative embryos of each developmental stage (3.5 dpc compact morulae, blastocysts and expanded blastocysts, and $4.5 \mathrm{dpc}$ hatched blastocysts) are shown. For each pluripotency and differentiation gene markers, two representative embryos of each developmental stage are shown. Ladder: DNA ladder with 50 bp increments; the arrow $(\rightarrow)$ signals the 50 bp mark; C+: positive control gene; for each analyzed gene, a tissue sample known to transcribe the analyzed gene was added, and the qRT-PCR reaction product added in the gel (see Methods section for details); NTC: non-template control

transcription, individual EBL of control and treated groups were analyzed by qRT-PCR for transcription of Notch1, Notch2, Jagged1, Jagged2, Hes1, Sox2, Oct4, Klf4, $C d x 2, \operatorname{Lgr} 5$ and Cdca7. Transcription of this latter pluripotency gene ( $\mathrm{Cdca7}$ ), regulated by Notch in later embryonic events, such as hematopoietic stem cell emergence [29], was here detected at this earlier stage of development. As shown in Fig. 6 a-j, Notch signaling blockade by DAPT downregulated transcription of Hes 1 and Sox $2(p<0.0001)$ and tended to decrease $(p=0.06)$ transcription of Notch2. Supplementation with Jagged1 decreased Jagged1 transcription (although nonsignificantly) and had no effect on Jagged 2 transcription. In contrast and interestingly, supplementation with Jagged2 although not affecting its own transcription, abolished Jagged 1 transcription in all but one embryo, and downregulated $C d x 2$ transcription. The presence of transcripts of Jagged 1, Jagged 2 and $C d x 2$ following treatments with DAPT, Jagged1 and Jagged2 was further confirmed by qRT-PCR product visualization in agarose gels
(Fig. 6 k). Additionally, the transcription of the negative control $\operatorname{Lgr} 5$ was not detected.

Correlation analysis showed that control $4.0 \mathrm{dpc}$ EBL showed a positive strong correlation between Hes 1 and Cdca7 $(r=0.98 ; p=0.005)$. A similar correlation was found in DAPT treated embryos $(r=0.98 ; p=0.001)$, but was not present in Jagged1 $(p=0.32)$ and Jagged2 $(p=$ 0.32 ) supplemented embryos.

\section{Discussion}

To the author's best knowledge, this is the first report on the dynamics of transcription of Notch and of markers of embryonic pluripotency and differentiation genes in individual embryos, from the time of the first cellular differentiation to blastocyst hatching. The results indicate that transcription of Notch components is highly dynamic during mouse blastocyst development and hatching. This approach allowed the assessment of gene transcription relationships, at the individual embryo level, providing so far unique data, not available 

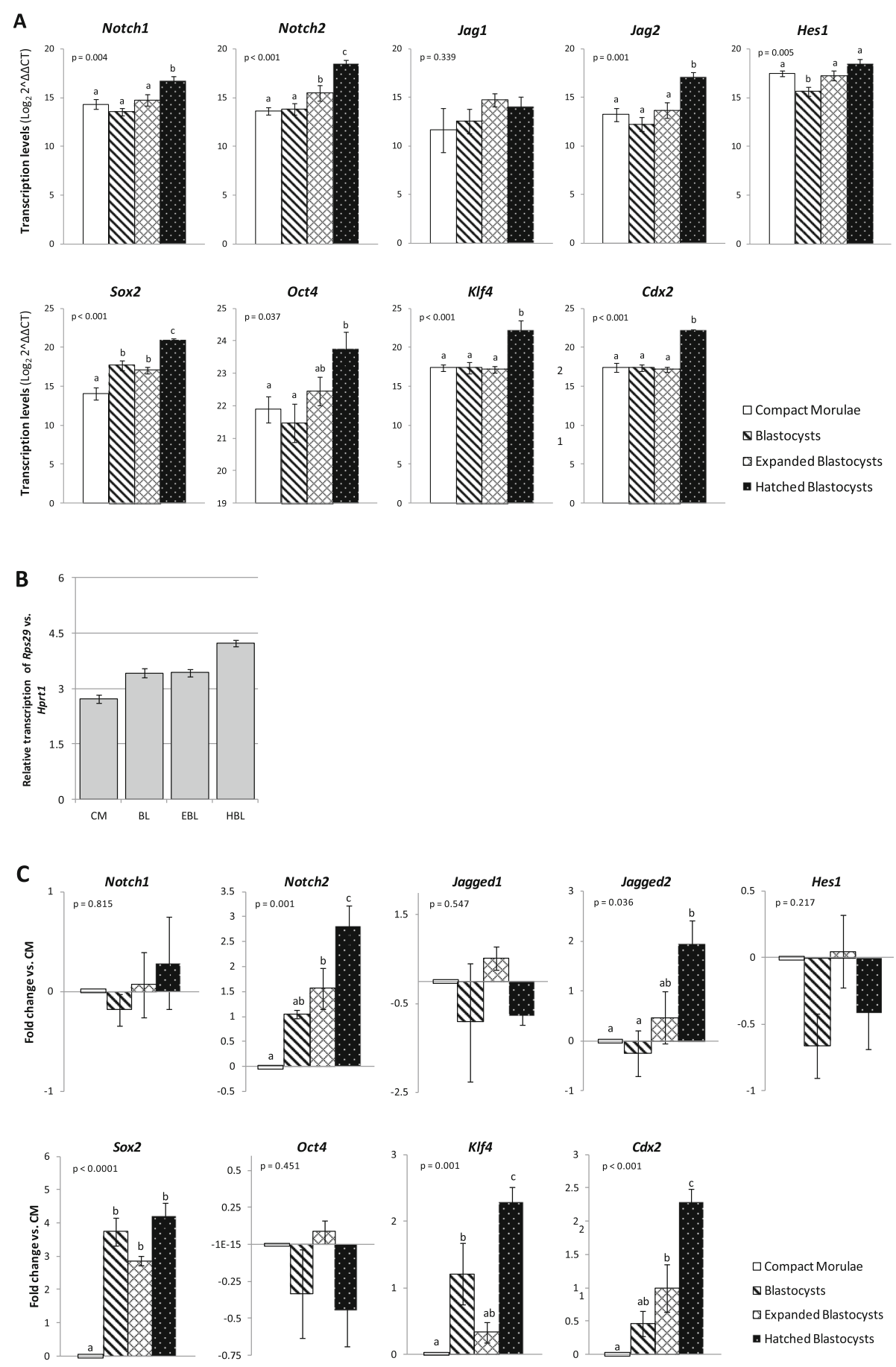

$\square$ Compact Morulae

ه Blastocysts

$\checkmark$ Expanded Blastocysts

- Hatched Blastocysts

Fig. 2 (See legend on next page.) 
(See figure on previous page.)

Fig. 2 Transcription of Notch components and pluripotency and differentiation gene markers in mouse early embryonic development.

Quantitative real-time (qRT-PCR) was used to detect and quantify the presence of transcripts in $3.5 \mathrm{dpc}$ compact morulae $(n=9)$, blastocysts $(n=$ 9) and expanded blastocysts $(n=7)$, and in $4.5 \mathrm{dpc}$ hatched blastocysts $(n=5)$. Analyzed genes (most prevalent): Notch receptors - Notch1 and Notch2; Notch ligands - Jagged1 and Jagged2; Notch effectors - Hes 1; Pluripotency and differentiation marker genes - Sox2, Oct4, KIf4 and Cdx2. Bars represent mean transcription levels \pm s.e.m. ANOVA $p$ values are indicated for each gene analysis. Bars with different letters differ significantly (post-hoc LSD). a: For data analysis, Ct values were normalized to housekeeping gene 1 (Rps29) and the $\Delta$ Ct values obtained further calibrated with housekeeping gene 2 (Hprt 1), generating $\Delta \Delta C$ t values. These values were log transformed and results presented as the $\log _{2}$ of power of $\Delta \Delta C$ t values. b: $\log _{2}$ of power of $\Delta C$ t values of transcription levels of housekeeping genes Rps 29 and Hprt1 at each developmental stage; $C M=$ Compact Morulae; $\mathrm{BL}=$ Blastocyst; $\mathrm{EBL}=$ Expanded Blastocyst; $\mathrm{HBL}=$ Hatched Blastocyst. $\mathbf{c}$ : For data analysis, $\mathrm{Ct}$ values of each target gene were normalized with the mean Ct values of housekeeping genes Rps 29 and Hprt1, and the obtained $\Delta \mathrm{Ct}$ values were then calibrated to $\Delta \mathrm{Ct}$ values of compact morulae (shown as 0.0 ), originating the $\Delta \Delta C \mathrm{Ct}$ values for log transformation. Results are also presented as the $\log _{2}$ of power of $\Delta \Delta C$ t values

from studies with pools of embryos or isolated blastomeres. This individual embryo approach revealed that transcription of Notch1, Notch2, Jagged1, Jagged2 and Hes1 was ubiquitous from the CM to HBL stages, whereas transcription of Notch3, Notch4, Dll4 and Hes2 was inconsistent along those developmental stages. These transcription patterns of Notch genes partially deviate from those reported by Cormier et al. [14], who evaluated transcription in pools of mouse embryos by nested RT-PCR (inconsistencies between studies in Notch3, Notch4, Dll1 and Dll4 transcription patterns). In the present study, the high accuracy and sensitivity of
qRT-PCR, as well as the confirmation of amplicon sequence, allowed for the exclusion of false positives resulting from unspecific amplifications of similar strands of nucleotides, as well as the detection of very small amounts of mRNA copies from single embryos. Recent studies used RNA-Seq analysis of single mouse blastomeres to identify several species of mRNA [18, 19]. Although this is a very useful approach to evaluate overall transcription status of a given cell, a full scan of the whole embryonic cells, especially of more advanced stages, such as HBL which can comprise up to 70 cells [30], is still not available. Since intercellular

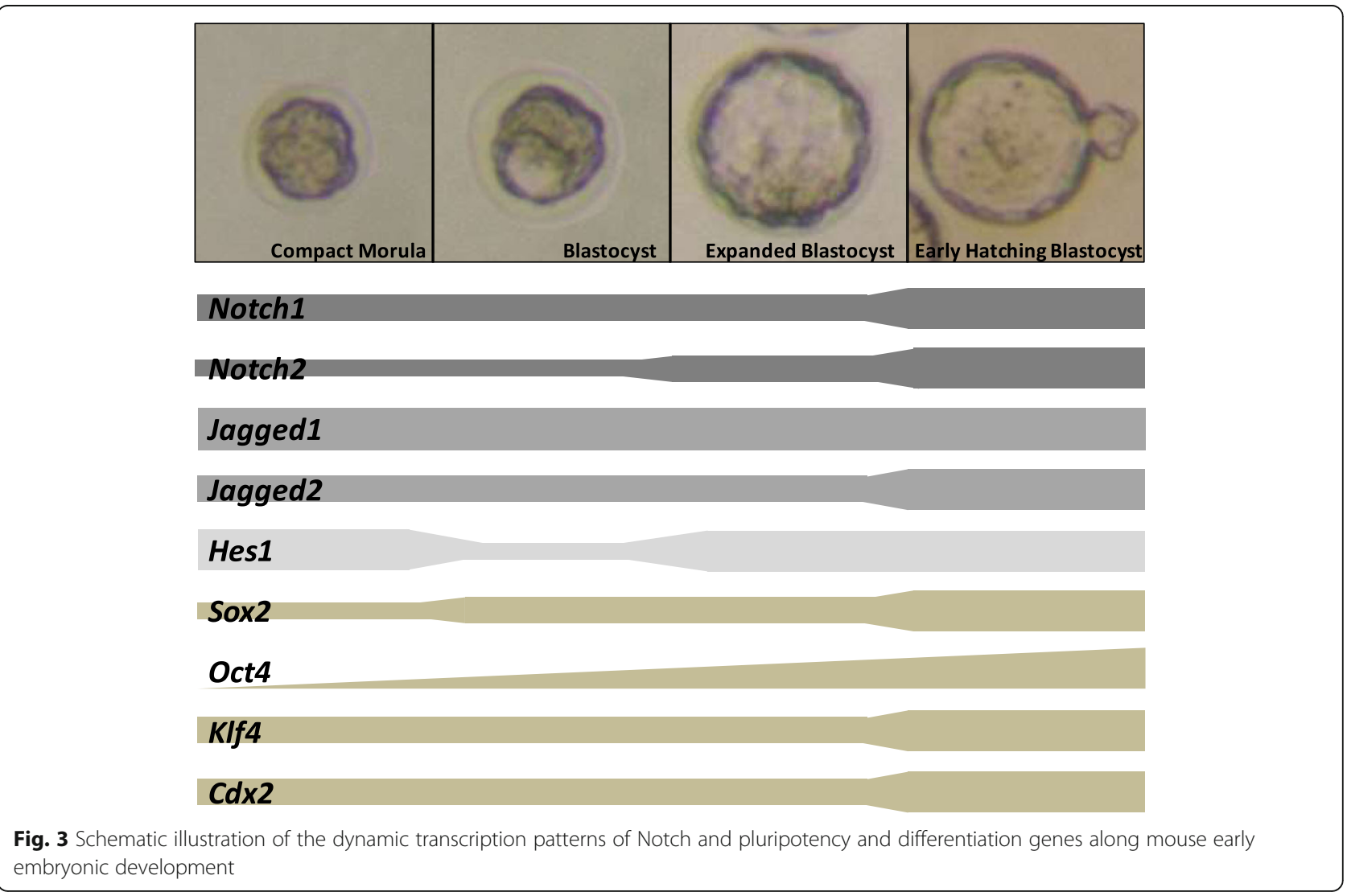




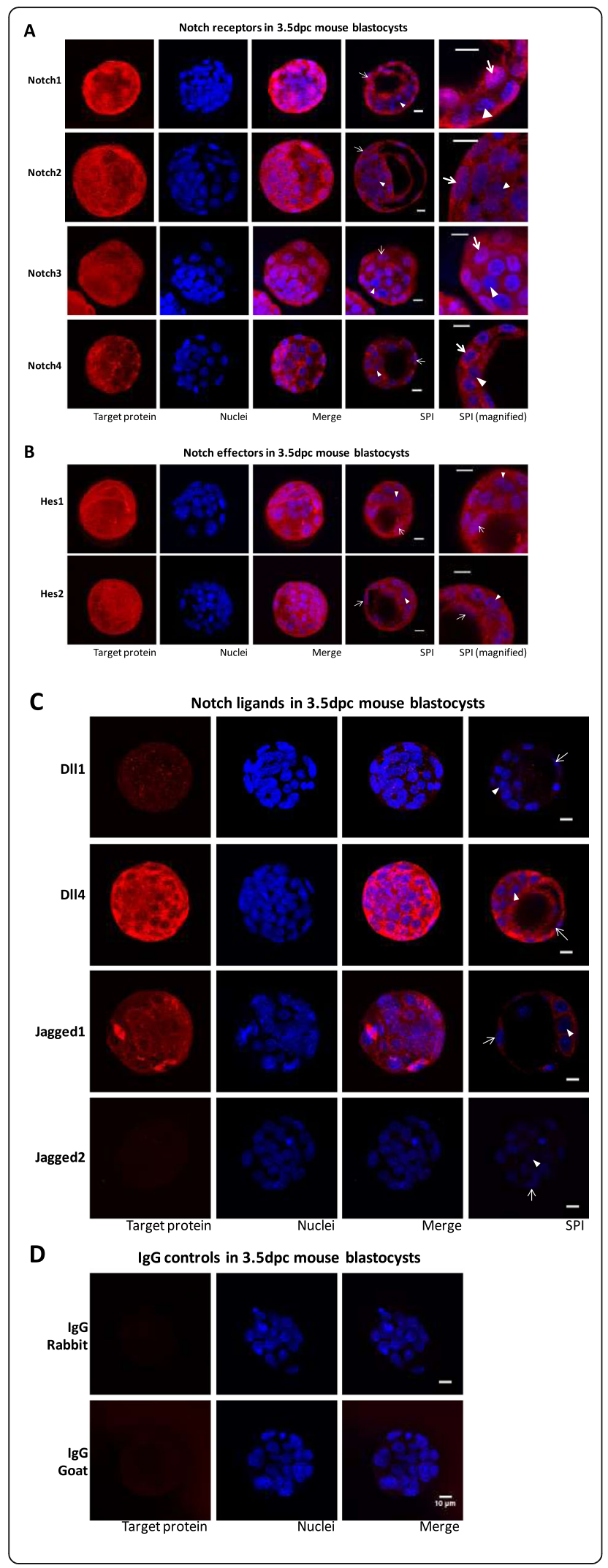

Fig. 4 Expression of Notch receptors Notch1-4 (a), Notch effectors Hes1-2 (b), Notch ligands Delta-like1 and 4 and Jagged1-2 (c), and negative controls (Rabbit and Goat lgG; d) in 3.5 dpc blastocysts. Confocal photomicrographs show representative images of each target protein immunostaining. Images were selected to show the similar staining pattern of six blastocysts, for each protein. Target proteins are stained red and nuclei are stained blue with Hoechst. Images in the first three columns are maximum intensity projections of the obtained Z-stack; the fourth and fifth columns are representative single plane images (SPI). Examples of presumptive trophectoderm cells' nuclei are marked with arrows $(\rightarrow)$ and examples of presumptive inner cell mass cells' nuclei are marked with arrowheads $(\boldsymbol{\vee})$. Scale bar $10 \mu \mathrm{m}$. Notice that there is no detectable staining for DII1 and Jagged2 proteins, which show a similar staining to that of negative controls

communication requires the analysis of both the signal sending and signal receiving cells, the loss of information from either of these cells, will provide an incomplete picture of embryonic gene transcription. In fact, in the above studies $[18,19]$ a low number of copies of Notch2, Dll4, Jagged1, Jagged2 and Hes2 transcripts were detected, or were not detected at all. This could be due not only to individual embryo variability, as also observed by others [28], but also to the individual blastomere signaling status, which could be in either a signal sending or signal receiving state, since they are mutually exclusive [31].

The presence of transcripts in embryos needs to be interpreted with caution, since an oocyte mRNA pool may be present and be responsible for protein production before the activation of the embryonic genome [32]. Although most of this mRNA pool is translated into protein and degraded during maternal to embryonic transition, which in the mouse occurs mainly at the 2cell stage [33], up to $10 \%$ of maternal mRNA persists until the BL stage [34]. Additionally, cells have posttranscriptional regulating mechanisms that allow them to stock mRNA without immediately translating it into protein [35]. This means that the presence of transcripts may not reflect the protein composition of an embryo at a given stage. In fact, in BL, although Notch4 and Dll4 transcripts were not detected, Notch4 and Dll4 proteins were detected. These proteins may have been translated at previous embryonic stages and have not yet been degraded. Inversely, Jagged2 transcripts were detected in all embryos, but Jagged2 protein was not expressed in BL. At this stage, the embryo may be merely storing Jagged 2 mRNA, which will be translated at a later stage. In fact, the translation of the accumulated Jagged 2 transcripts may only occur at hatching when the embryo enters in direct contact with the endometrium. In this scenario, Jagged 2 may be involved, both in the hatching process and in embryo-maternal communication, since 
Table 2 Effect of embryo culture supplementation with DAPT, Jagged1 and Jagged2 on mouse embryo survival

\begin{tabular}{lllllll}
\hline Group & $\mathrm{n}$ & $3.5 \mathrm{dpc}$ embryos $\mathrm{n}(\%)$ & $\mathrm{n}$ & $4.0 \mathrm{dpc}$ embryos $\mathrm{n}(\%)$ & $\mathrm{n}$ & $4.5 \mathrm{dpc}$ embryos $\mathrm{n}(\%)$ \\
\hline Control & 216 & $200(93 \%)$ & 192 & $176(92 \%)$ & 127 & $114(90 \%)$ \\
DAPT & 86 & $77(90 \%)$ & 88 & $78(89 \%)$ & 26 & $21(81 \%)$ \\
Jagged1 & 146 & $131(90 \%)$ & 128 & $120(94 \%)$ & 108 & $95(88 \%)$ \\
Jagged2 & 102 & $97(95 \%)$ & 103 & $99(96 \%)$ & 40 & $32(80 \%)$ \\
\hline
\end{tabular}

Columns marked as $\mathbf{n}$ show the total number of embryos present in culture; columns marked as $3.5 \mathrm{dpc}, 4.0 \mathrm{dpc}$ and $4.5 \mathrm{dpc}$ show the number of nondegenerated morphologically normal embryos progressing in culture up to that time-point

several Notch receptors and effectors were identified in the mouse uterine epithelium [36].

Notch1 transcription was constant until the EBL stage, increasing at the HBL stage, and signaling was activated through this receptor, as the protein was detected in the nucleus. This may indicate that besides a constitutive function [26-28] Notch1 may be regulating other cell functions. Notch3 was also detected in the nucleus of embryonic cells, which indicates that Notch signaling is also being activated through this receptor. On the other hand, as Notch2 remains in the cytoplasm and, since Notch receptors are not redundant [37], results indicate that, at this embryonic stage, only Notch1 and Notch3 are being required. Effector Hes1 was detected in the nucleus, whereas Hes2 only showed a diffuse staining pattern in the cytoplasm. This indicates that Notch signaling may be conveyed through Hes1. In this scenario, as Jagged2 is not expressed at the BL stage, Jagged1 appears as the ligand involved in canonical Notch receptor activation. The diffuse pattern accumulation of Hes 2 in the cytoplasm after translation, without translocation to the nucleus, was already observed in other scenarios [38]. This may indicate an additional regulatory mechanism for conveying Notch activity in embryos. Further studies are required to investigate the participation of other Notch effectors, such as the Hey gene family [39], or if Notch signaling is established non-canonically, namely by interacting with other signaling pathways such as Wnt [23] and Hippo [13, 27, 28].

Transcription of embryonic pluripotency and differentiation gene markers followed the patterns previously described by others $[15,18,40]$. The transcription levels of these genes were correlated with those of Notch genes, suggesting that they may be the target of Notch signaling or, conversely, operate to modulate Notch signaling. Menchero et al. [28] showed that Notch is a major activator of $C d x 2$ transcription from the 2-cell to the morula stage, but from this stage until the blastocyst stage, $C d \times 2$ transcription is activated by Hippo. In this study, transcription of $C d x 2$ correlated with those of Notch1, Notch2, Jagged2 and Hes1. Therefore, Notch may still be regulating $C d x 2$ transcription at the $\mathrm{BL}$ stage.

The presence of Notch signaling activity was further confirmed by the observed downregulation of its effector
Hes1, following DAPT treatment. This pharmacological blockade of Notch signaling affected embryo developmental kinetics, retarding blastocyst hatching, and downregulated Sox2 transcription. The above effect on blastocyst hatching was also observed following Jagged2 supplementation. This indicates that a deregulation in Notch signaling, either by its over or under-activation, affects blastocyst development and hatching.

Modulation of Notch signaling through its serrated type ligands has been widely used in many pathological scenarios. The use of anti-Jagged or Jagged overexpression therapies has been extensively studied with varying results [41-43]. Jagged1 supplementation had no major effect on embryo developmental kinetics. This could be due to a sufficient expression of this ligand by the embryo itself, turning supplementation redundant. Interestingly, Jagged2 supplementation abolished Jagged1 transcription, and this was associated with a downregulation of $C d x 2$ transcription and with an impaired blastocyst hatching. This indicates that Jagged2 supplemented embryos had no internal or external source of Jagged1 to maintain a satisfactory $C d x 2$ transcription level. This points to a regulatory mechanism by which Jagged1 controls $C d x 2$ transcription, and the completion of blastocyst hatching. Alternatively, as $\mathrm{Cdx} 2$ is not believed to be an active participant in this process [27], it is possible that Jagged1 is linked to blastocyst hatching through its interplay with other cell signaling pathways.

Notch signaling activates Cdca7 transcription in hematopoietic stem cell specification during zebrafish embryonic development [29]. Here, in the mouse model, transcription of Cdca7 was ubiquitously detected at a much earlier embryonic developmental stage. Transcription of Cdca7 correlated with that of Hes1, in control and DAPT-treated embryos. Both Hes1 and Cdca7 have promoters with Rbpj-binding sites, being potential Notch transcriptional targets. However, transcription of Hes1 was downregulated by DAPT treatment, whereas Cdca7 transcription was not affected. This may indicate that Notch is not regulating $\mathrm{Cdca} 7$ transcription in this mammalian embryonic stage scenario. Nevertheless, the observed significant correlation between Hes1 and Cdca7 deserves further investigation. 

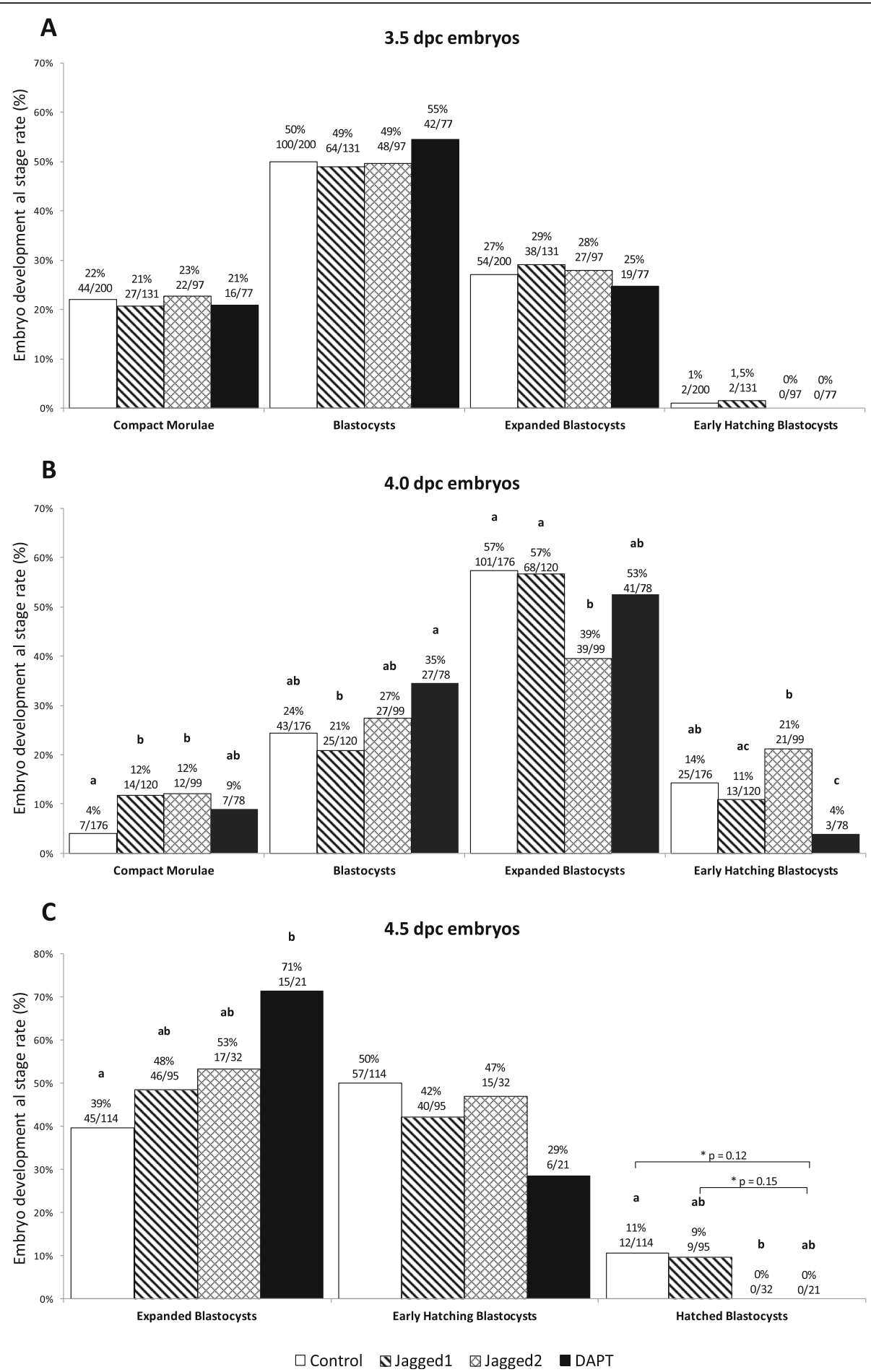

Fig. 5 Effect of pharmacological Notch signaling inhibition and activation on mouse embryo developmental kinetics. Mouse 2.5 dpc embryos were in vitro cultured in the presence of a Notch inhibitor (DAPT) or Notch ligands Jagged 1 and Jagged 2 until 4.5 dpc. Embryos were observed after $24 \mathrm{~h}$ in culture (at $3.5 \mathrm{dpc} ; \mathbf{a}$ ), $36 \mathrm{~h}$ in culture (at $4.0 \mathrm{dpc} ; \mathbf{b}$ ) and $48 \mathrm{~h}$ in culture (at $4.5 \mathrm{dpc} ; \mathbf{c}$ ) and morphologically evaluated. In vitro culture of a subset of embryos was discontinued at $3.5 \mathrm{dpc}$ or $4.0 \mathrm{dpc}$ to perform transcription analysis. Numbers above bars indicate the number of viable embryos in culture / the number of total embryos. Different letters within the same developmental stage differ significantly, $p<0.05$ (Chisquare test). Asterisks $\left(^{*}\right)$ indicate the exact $p$ value of the Chi-square test 


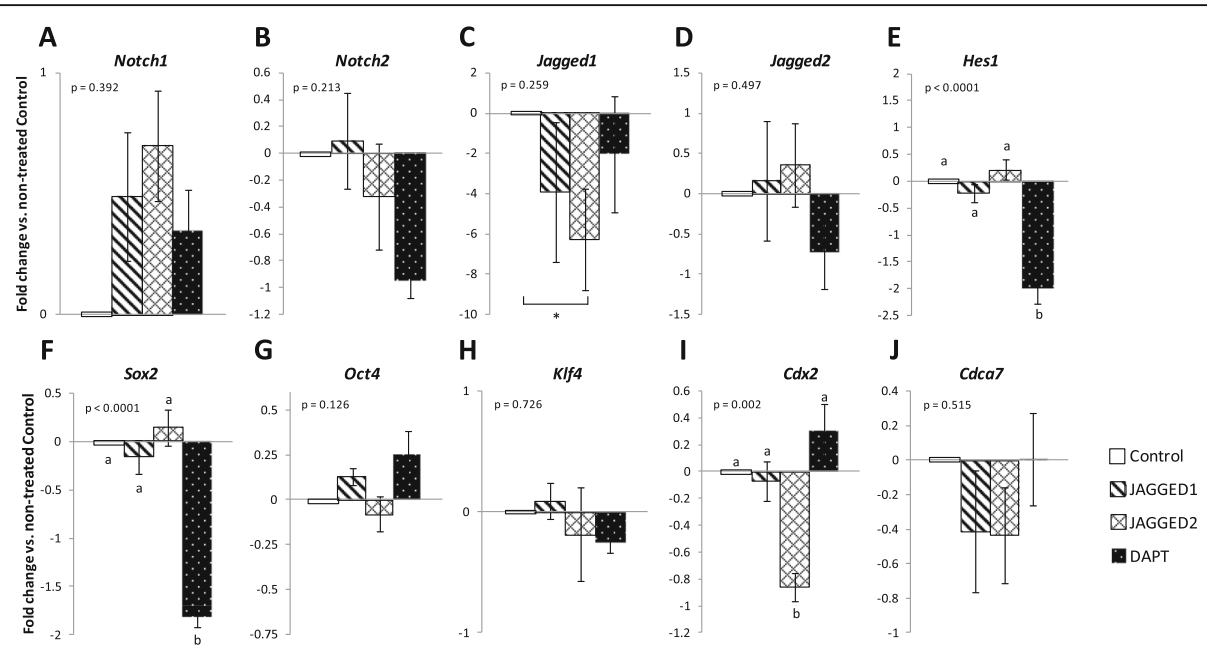

\section{K}

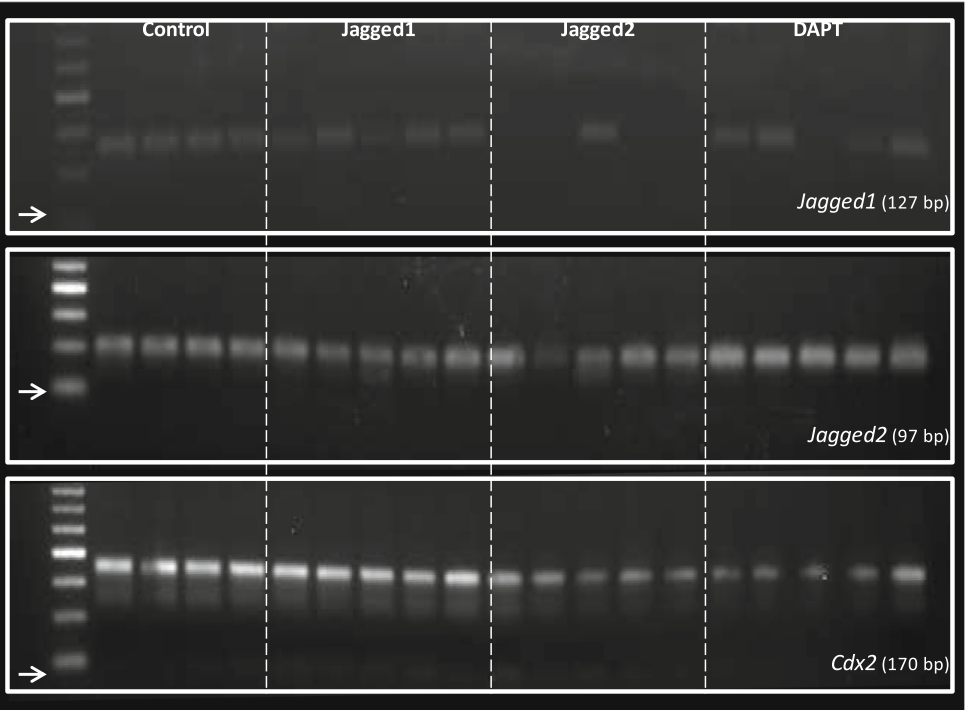

Fig. 6 Effect of pharmacological Notch signaling inhibition and activation on gene transcription in $4.0 \mathrm{dpc}$ mouse expanded blastocysts. Mouse $2.5 \mathrm{dpc}$ embryos were in vitro cultured in the presence of a Notch inhibitor (DAPT) or of Notch ligands Jagged1 and Jagged2, for $36 \mathrm{~h}$, until 4.0 dpc. Expanded blastocysts from groups Control $(n=5)$, Jagged1-treated $(n=5)$, Jagged2-treated $(n=5)$ and DAPT-treated $(n=6)$ were processed for qRT-PCR analysis. a-j: Transcription of Notch1 (a), Notch2 (b), Jagged1 (c), Jagged2 (d) and Hes1 (e), and of pluripotency and differentiation genes Sox2 (f), Oct4 (g), KIf4 (h), Cdx2 (i) and Cdca7 (j) were analyzed. Bars represent $\log _{2}$ of power of $\Delta \Delta C t$ values. These values were generated by first normalizing the Ct values of each target gene with the mean Ct values of the endogenous control genes Rps29 and Hprt1. The obtained $\Delta \mathrm{Ct}$ values were then calibrated to $\Delta \mathrm{Ct}$ values of Control embryos, which were used as calibrators (shown as 0.0 ), originating the $\Delta \Delta \mathrm{Ct}$ values for log transformation; error bars show the standard error of the mean (s.e.m). Exact ANOVA results ( $p$ ) are shown for each gene. Different letters within the same gene represent significantly different mean values $\left(p<0.05\right.$; LSD post-hoc). ${ }^{*}$ Transcription of Jagged 1 differs significantly $(p=$ 0.038) between groups Control and Jagged2-treated (T-test). k: Agarose gels of qRT-PCR products of genes Jagged1, Jagged2 and Cdx2. Images illustrate results from representative $4.0 \mathrm{dpc}$ expanded blastocysts from groups Control $(n=4)$, Jagged1-treated $(n=5)$, Jagged2-treated $(n=5)$ and DAPT-treated $(n=5)$. The DNA ladder has 50 bp increments, and the arrow $(\rightarrow)$ signals the 50 bp mark

\section{Conclusions}

In conclusion, this study characterized the transcription and expression of Notch pathway components (receptors, ligands and effectors) at the individual embryo level, during mouse blastocyst development and hatching. The transcription levels of Notch genes followed a dynamic pattern along development. Transcription levels of Notch1, Notch2, Jagged2 and Hes1 correlated with each other and with those of pluripotency and differentiation genes. Gene transcription was associated to protein expression, except for Jagged2, where high transcription levels in all embryos were not translated into protein, 
possibly reflecting mRNA storage for use at a later stage of development and/or interaction with the endometrium. Presence of Notch signaling activity was confirmed through nuclear NICD and Hes1 detection, and downregulation of Hes1 transcription following canonical signaling blockade with DAPT. Data lead to the suggestion that Notch canonical signaling may be operating through Notch1, Notch3, Jagged1 and Hes1. In vitro embryo culture supplementation with Jagged1 had no effect on embryo developmental kinetics. In contrast, supplementation with Jagged2 abolished Jagged 1 transcription, downregulated $C d x 2$ transcription and inhibited blastocyst hatching. This unveiled a possible regulatory effect between Jagged1, Cdx2 and blastocyst hatching. Notch signaling blockade by DAPT downregulated transcription of Sox2, and retarded embryo hatching. This indicates that a deregulation in Notch signaling, either by its over or under-activation, affects blastocyst development and hatching.

\section{Methods \\ Animals}

Animal manipulation and experimental procedures were conducted according to the national and European Union legislation regarding the use of animals for experimental purposes, and under the license of the national regulatory agency (DGAV - Direção Geral de Alimentação e Veterinária) and Institutional Animal Care and Use Committee (CEBEA - Comissão de Ética e Bem-Estar Animal; Ref. 001/2018). Male and female Crl: CD1 (ICR) (CD1) mice were purchased from Charles River Laboratoire France and maintained at the Faculty of Veterinary Medicine of the University of Lisbon animal house facilities. Mice were maintained in a $12 \mathrm{~h}$ light/dark cycle, in corn cob bedded cages and with ad libitum access to standard laboratory diet and water. Mouse health was monitored daily.

\section{Embryo collection and in vitro culture}

Embryos were obtained from 2 to 3 months-old CD1 female mice, following superovulation and mating with CD1 males. Briefly, females were injected intraperitoneally with $10 \mathrm{IU}$ equine chorionic gonadotropin (Intergonan; MSD Animal Health, Portugal) and $46 \mathrm{~h}$ later with $10 \mathrm{IU}$ human chorionic gonadotropin (hCG; Chorulon; MSD Animal Health). Females were then housed overnight with a male and the presence of a vaginal plug was checked the following morning $(0.5 \mathrm{dpc})$. At $2.5 \mathrm{dpc}$, females were euthanized by cervical dislocation under general anesthesia (intraperitoneal injection with $150 \mathrm{mg}$ $\mathrm{kg}^{-1}$ ketamine $+10 \mathrm{mg} \mathrm{kg}^{-1}$ xylazine) and embryos were collected by oviduct flushing with M2 medium (SigmaAldrich, St Louis, MO, USA). Morphologically normal 8 to 16-cell embryos were selected, washed in M2 medium and in vitro cultured in groups of 20 in $500 \mu \mathrm{l}$ of KSOM (Millipore, Specialty Media, Germany) overlaid with $400 \mu \mathrm{l}$ of mineral oil (EmbryoMax ${ }^{\circ}$, Millipore), in 4-well dishes (Nunclon, Nunc, Roskilde, Denmark), at $37^{\circ} \mathrm{C}$ in a $90 \% \mathrm{~N}_{2}+5 \% \mathrm{O}_{2}+5 \% \mathrm{CO}_{2}$ humidified atmosphere. Following a 24, 36 and $48 \mathrm{~h}$ culture (corresponding to respectively $3.5 \mathrm{dpc}, 4.0 \mathrm{dpc}$ and $4.5 \mathrm{dpc}$ ), embryos were classified into the CM, BL, EBL, eHBL (early HBL) and HBL developmental stages, according to Nagy et al. (2003) [44] (Fig. 6).

\section{Gene transcription analysis - qRT-PCR}

Quantification of transcripts of Notch components - receptors (Notch1, Notch2, Notch3 and Notch4), ligands (Delta-like1 - Dll1, Delta-like4 - Dll4, Jagged1 and Jagged2), and effectors (Hes1 and Hes2) - and of transcripts of pluripotency and differentiation gene markers Sox2, Klf4, Oct4, Cdx2, Cdca7 and Lgr5 was analyzed in individual $3.5 \mathrm{dpc} \mathrm{CM}(n=9)$, BL $(n=9)$ and EBL $(n=7)$ and $4.5 \mathrm{dpc} \mathrm{HBL}(n=5)$. Overall, transcription was individually evaluated in 30 embryos.

RNA extraction of single embryos was performed using the Arcturus ${ }^{\circ}$ PicoPure $^{\mathrm{Tu}}$ RNA Isolation Kit (Applied Biosystems, ThermoFisher Scientific, USA) and DNA digestion with RNase-free DNase Set (Qiagen, Hilden, Germany). Concentration and purity of RNA were assessed spectrophotometrically at 260 and $280 \mathrm{~nm}$ (NanoDrop ${ }^{\circ} 2000$ c, ThermoFisher Scientific). Complimentary DNA (cDNA) synthesis was performed using Maxima First Strand cDNA Synthesis Kit for RTqPCR (ThermoFisher Scientific) using $20 \mathrm{ng}$ of total RNA in each reaction. Pre-amplification of cDNA was achieved with SSoAdvanced ${ }^{\mathrm{Tm}}$ PreAmp Supermix (BioRad, CA, USA) using $10 \mu \mathrm{l}$ of undiluted cDNA and a primer pool of genes Notch1-4, Dll1 and Dll4, Jagged12, Hes1-2, Sox2, Klf4, Oct4, Cdx2, Lgr5, and reference genes Rps29 and Hprt1 (Table 3). With the exception of Sox2, which is coded by a single exon, primers were designed to bracket two exons to avoid genomic DNA amplification. In the case of Sox2, the cDNA specific amplification was confirmed with a minus-reverse transcriptase control.

Pre-amplified cDNA was diluted 1:10 in Tris-EDTA buffer and kept at $-20^{\circ} \mathrm{C}$ until qRT-PCR analysis. This was performed in duplicate wells in StepOne Plus ${ }^{\text {Th }}$ (Applied Biosystems, ThermoFisher Scientific) in 96-well optical reaction plates (Applied Biosystems), using the universal temperature cycles: $10 \mathrm{~min}$ of pre-incubation at $95^{\circ} \mathrm{C}$, followed by 40 two-temperature cycles $(15 \mathrm{~s}$ at $95^{\circ} \mathrm{C}$ and $1 \mathrm{~min}$ at $60^{\circ} \mathrm{C}$ ). Melting curves were acquired to ensure that a single product was amplified in the reaction. Each reaction used $10 \mu \mathrm{l}$ of Perfecta ${ }^{\circ}$ Sybr $^{\circ}$ Green Fast Mix, ROX ${ }^{\mathrm{m}}$ (Quanta bio, MA, USA), $2 \mu$ of diluted pre-amplified cDNA (corresponding to $0.2 \mathrm{ng}$ of $\mathrm{cDNA}$ ) 
Table 3 Primer sequences for target genes

\begin{tabular}{|c|c|c|c|}
\hline Target gene & Sequence $\left(5^{\prime}-3^{\prime}\right)$ & Product length (bp) & Accession no. \\
\hline Notch1 & $\begin{array}{l}\text { Fwd: ACAGTAACCCCTGCATCCAC } \\
\text { Rev.: GGTTGGACTCACACTCGTTG }\end{array}$ & 120 & NM_008714.3 \\
\hline Notch2 & $\begin{array}{l}\text { Fwd: GACTGCACAGAAGACGTGGA } \\
\text { Rev:: GCGTAGCCCTTCAGACACTC }\end{array}$ & 116 & NM_010928.2 \\
\hline Notch3 & $\begin{array}{l}\text { Fwd: GTGTCAATGGTGGTGTCTGC } \\
\text { Rev.: GCACACTCATCCACATCCAG }\end{array}$ & 103 & NM_008716.2 \\
\hline Notch4 & $\begin{array}{l}\text { Fwd: GAGGGACACTCCACCTITCA } \\
\text { Rev:: CTGGTGCCTGACACAGTCAT }\end{array}$ & 93 & NM_010929.2 \\
\hline Delta-like1 & $\begin{array}{l}\text { Fwd: GTTGTCTCCATGGCACCTG } \\
\text { Rev:: TGCACGGCTTATGGTGAGTA }\end{array}$ & 111 & NM_007865.3 \\
\hline Delta-like4 & $\begin{array}{l}\text { Fwd: GGAACCTTCTCACTCAACATCC } \\
\text { Rev.: CTCGTCTGTTCGCCAAATCT }\end{array}$ & 141 & NM_019454.3 \\
\hline Jagged 1 & $\begin{array}{l}\text { Fwd: CCAGCCAGTGAAGACCAAGT } \\
\text { Rev:: CAATTCGCTGCAAATGTGTT }\end{array}$ & 127 & NM_013822.5 \\
\hline Jagged2 & $\begin{array}{l}\text { Fwd: AGTGCCATCTGGCTTTGAAT } \\
\text { Rev:: CGCTGCACATGGGTTAGAG }\end{array}$ & 97 & NM_010588.2 \\
\hline Hes 1 & $\begin{array}{l}\text { Fwd: GCGAAGGGCAAGAATAAATG } \\
\text { Rev:: TGTCTGCCTTCTCTAGCTTGG }\end{array}$ & 104 & NM_008235.2 \\
\hline Hes2 & $\begin{array}{l}\text { Fwd: CGGATCAACGAGAGCCTAAG } \\
\text { Rev.: GTCTGCCTTCTCCAACTTCG }\end{array}$ & 93 & NM_001301805.1; NM_008236.4 \\
\hline Sox2 & $\begin{array}{l}\text { Fwd: GGTTCTTGCTGGGTTTGATTCT } \\
\text { Rev:: CCTTCCTTGTTTGTAACGGTCCT }\end{array}$ & 59 & NM_011443.4 \\
\hline Klf4 & $\begin{array}{l}\text { Fwd: GCAGTCACAAGTCCCCCTCTC } \\
\text { Rev:: GACCTTCTTCCCCTCTTTGG }\end{array}$ & 93 & NM_010637.3 \\
\hline Oct4 & $\begin{array}{l}\text { Fwd: TGGAGGAAGCCGACAACAAT } \\
\text { Rev:: GCTGATTGGCGATGTGAGTG }\end{array}$ & 177 & NM_001252452.1; NM_013633.3 \\
\hline$C d \times 2$ & $\begin{array}{l}\text { Fwd: CTGGCTCCGCAGAACTTTGT } \\
\text { Rev:: GGTGCGTAGCCATTCCAGTC }\end{array}$ & 170 & NM_007673.3 \\
\hline Cdcal & $\begin{array}{l}\text { Fwd: ACA TGC TGG TGA GAC AGA GGA A } \\
\text { Rev.: TAT ATG CGG AAG GGT CAT GGA }\end{array}$ & 98 & NM_025866.3 \\
\hline Lgr5 & $\begin{array}{l}\text { Fwd: CCC ATC CAA TाT GTT GGA GTA } \\
\text { Rev:: GTG GCA GTT CCT GTC AAG TG }\end{array}$ & 113 & NM_010195.2 \\
\hline $\operatorname{Rps} 29$ & $\begin{array}{l}\text { Fwd: CACGGTCTGATCCGCAAATAC } \\
\text { Rev:: ACTAGCATGATCGGTTCCACTTG }\end{array}$ & 144 & NM_009093.2 \\
\hline Hprt1 & $\begin{array}{l}\text { Fwd: GTCGTGATTAGCGATGATGAACC } \\
\text { Rev.: GCAAGTCTTCAGTCCTGTCCATAA }\end{array}$ & 128 & NM_013556.2 \\
\hline
\end{tabular}

and $80 \mathrm{nM}$ of each primer in a total reaction volume of $20 \mu \mathrm{l}$. A NTC (no-template control) was included in all reaction plates and only plates with undetermined $\mathrm{Ct}$ in NTC wells were analyzed. Also, only wells with a single specific melting curve peak were analyzed. For each gene, one PCR product was run through a $2.5 \%$ agarose gel to confirm expected product size and the identity of this PCR product was confirmed by DNA sequencing. All reactions with the same Tm as the confirmed PCR product were considered specific. Positive controls were added to each reaction plate to exclude primer design artifacts: mouse uterus in oestrus for Notch1, Dll4 and Hes1 transcription, mouse uterus in metoestrus for Notch2, Notch 3 and Hes 2 transcription, mouse uterus in dioestrus for Notch4, Jagged1 and Jagged2 transcription [33], and mouse small intestine for Dll1 and Lgr5 [45].
Embryos themselves were used as positive controls for Sox2, Klf4, Oct4, Cdx2 and Cdca 7 transcription [18, 19].

The first step in transcription data analysis was the calculation of prevalence among embryos, i.e. the proportion of embryos with detected transcription at each developmental stage. Genes with a $\mathrm{Ct}$ value $>35$ were considered without amplification. This was further confirmed by visualization of qRT-PCR products in agarose gels (Table 1 and Fig. 1). The next step in transcription analysis was to quantify transcription levels of most prevalent genes. This was performed by two approaches. In Fig. 2 panel a, $\mathrm{Ct}$ values were normalized to housekeeping gene 1 (Rps29) and the $\Delta \mathrm{Ct}$ values obtained further calibrated with housekeeping gene 2 (Hprt1), generating $\Delta \Delta \mathrm{Ct}$ values. These values were log transformed and results presented as the $\log _{2}$ of power of 
$\Delta \Delta \mathrm{Ct}$ values. The $\log _{2}$ of power of $\Delta \mathrm{Ct}$ values of transcription levels of housekeeping genes Rps 29 and Hprt1 at each developmental stage are shown in Fig. 2 panel b. The second approach is shown in Fig. 2 panel c. Here, $\mathrm{Ct}$ values of each target gene were normalized with the mean Ct values of housekeeping genes Rps29 and Hprt1, and the obtained $\Delta \mathrm{Ct}$ values were then calibrated to $\Delta \mathrm{Ct}$ values of compact morulae (shown as 0.0 ), originating the $\Delta \Delta \mathrm{Ct}$ values for log transformation [46]. Results are also presented as the $\log _{2}$ of power of $\Delta \Delta C t$ values.

\section{Gene expression analysis - immunocytochemistry}

Embryos (3.5 dpc BL) were fixated in a $4 \%$ paraformaldehyde solution for $30 \mathrm{~min}$, at $4{ }^{\circ} \mathrm{C}$, permeabilized in phosphate-buffered saline (PBS) $+0.5 \%$ Triton X-100 for $1 \mathrm{~min}$ and washed in PBS. Blocking was performed in a PBS $+0.1 \%$ Tween 20 solution containing $2.5 \%$ bovine serum albumin (Sigma-Aldrich) for $1 \mathrm{~h}$ at room temperature, followed by a $4{ }^{\circ} \mathrm{C}$ overnight incubation with the primary antibody diluted in blocking solution. Primary antibodies, all polyclonal and already validated for use in mouse cells [36, 47], were diluted as presented in Table 4. Negative IgG controls were performed using rabbit polyclonal IgG (ab27478, Abcam) and goat polyclonal IgG (ab37373, Abcam) at the appropriate dilutions. Embryos were then washed in PBS $(4 \times 5 \mathrm{~min})$ and incubated with AlexaFluor 594 chicken anti-rabbit (A11012, Life Technologies, USA) or chicken anti-goat (A21468, Life Technologies) secondary antibody diluted 1:300 in blocking solution, according to primary antibody host species, for $30 \mathrm{~min}$, at room temperature. Embryos were then washed $2 \times 10 \mathrm{~min}$ in PBS followed by Hoechst33268 (Sigma-Aldrich) nuclear labeling and finally mounted in ProLong ${ }^{\text {tm }}$ Gold Antifade Mountant (Life Technologies). For each primary antibody, 6 blastocysts were analyzed, and a Z-stack was captured using a Zeiss LSM 710 confocal microscope (Carl Zeiss Microscopy, Oberkochen, Germany) with an optical magnification of $400 \times$ and treated with Fiji software (National Institutes of Health, USA).

\section{Embryo culture supplementation with notch ligands and a notch signaling inhibitor}

Mouse 8-16 cell embryos were collected and in vitro cultured as previously described, being randomly allocated in groups of 20 to each of the following treatment groups: i) Control, without treatment ii) Jagged1, medium supplemented with $1 \mu \mathrm{g} \mathrm{ml}^{-1}$ Jagged1 (1277-JG, R\&D Systems, Bio-Techne, USA); iii) Jagged2, medium supplemented with $1 \mu \mathrm{g} \mathrm{ml}^{-1}$ Jagged2 (4748-JG, R\&D Systems); and iv) DAPT, medium supplemented with $100 \mu \mathrm{M}$ DAPT (N-[N-(3,5-Difluorophenacetyl)-L-alanyl]-S-phenylglycine t-butyl ester; Sigma-Aldrich). The experiment considered 10 in vitro culture sessions (550 embryos) until $3.5 \mathrm{dpc}(24 \mathrm{~h})$, from which 9 sessions (511 embryos) were further cultured until $4.0 \mathrm{dpc}(36 \mathrm{~h})$, and from the latter, 6 sessions (301 embryos) were further cultured until $4.5 \mathrm{dpc}(48 \mathrm{~h})$. Embryos were evaluated for viability, expressed as non-degenerated morphologically normal embryos progressing in culture, and their developmental stage recorded at those timepoints (Fig. 7) by a technician blinded to group assignment, according to criteria established by Nagy et al. (2003) [44]. Five to six individual 4.0 dpc EBL from each group were processed for quantification of transcripts of Notch genes (Notch1-2, Jagged1-2, Hes1) and pluripotency and differentiation marker genes (Sox2, Klf4, Oct4, $C d x 2, C d c a 7)$, as described above.

\section{Statistical analysis}

Statistical analysis was performed using the statistical software SPSS Statistics (version 22, IBM ${ }^{\bullet}$ SPSS $^{\circledR}$ Statistics, 2013, IBM, NY, USA). Real-time PCR data $(\Delta \mathrm{Ct}$ values) did not follow normal distribution (Fig. S1) and were transformed to $\log 2$ of power of $\Delta \Delta C t$ for normalization, which allowed the use of parametric tests.

Table 4 Immunocytochemistry primary antibodies, dilutions and manufacturer and catalogue reference, as used by Murta et al. [36, 47]

\begin{tabular}{llll}
\hline Antibody & Source & Dilution & Supplier (catalogue number) \\
\hline anti-Notch1 & Rabbit polyclonal & $1: 100$ & Abcam (ab8925) \\
anti-Notch2 & Rabbit polyclonal & $1: 100$ & Abcam (ab8926) \\
anti-Notch3 & Rabbit polyclonal & $1: 200$ & Abcam (ab23426) \\
anti-Notch4 & Rabbit polyclonal & $1: 50$ & Santacruz Biotechnology (sc5594) \\
anti-DII1 & Rabbit polyclonal & $1: 100$ & Abcam (ab76655) \\
anti-DII4 & Rabbit polyclonal & $1: 200$ & Abcam (ab7280) \\
anti-Jagged1 & Rabbit polyclonal & $1: 50$ & Santacruz Biotechnology (sc8303) \\
anti-Jagged2 & Goat polyclonal & $1: 50$ & Santacruz Biotechnology (sc8158) \\
anti-Hes1 & Rabbit polyclonal & $1: 100$ & Abcam (ab71559) \\
anti-Hes2 & Rabbit polyclonal & $1: 100$ & Abcam (ab134685) \\
\hline
\end{tabular}




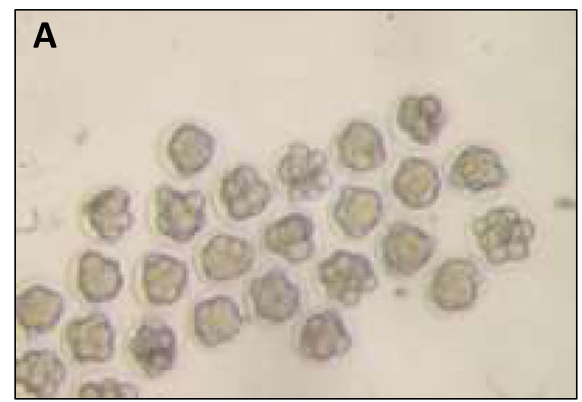

$2.5 \mathrm{dpc}$ mouse embryos

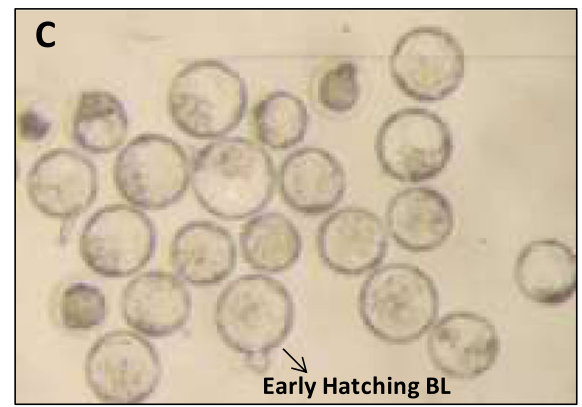

4.0dpc mouse embryos

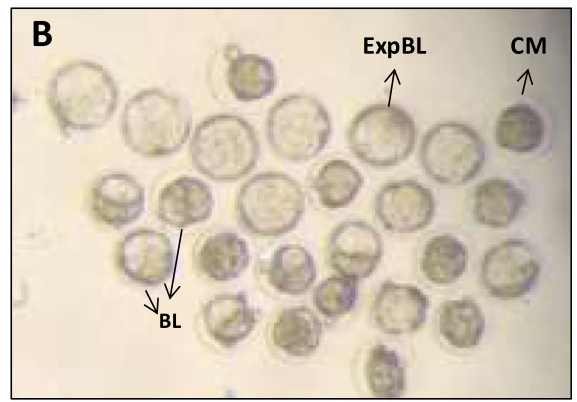

$3.5 \mathrm{dpc}$ mouse embryos

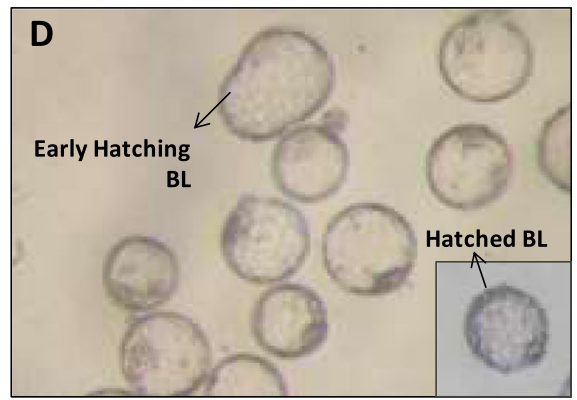

$4.5 \mathrm{dpc}$ mouse embryos

Fig. 7 Representative photographs illustrating the morphological staging of embryonic development. Mouse embryos were in vivo collected at $2.5 \mathrm{dpc}$ (a), in vitro cultured, and morphologically evaluated according to Nagy et al. 2003 [44] at $3.5 \mathrm{dpc}$ (cultured for 24 h; b), $4.0 \mathrm{dpc}$ (cultured for $36 \mathrm{~h} ; \mathbf{c}$ ) and $4.5 \mathrm{dpc}$ (cultured for $48 \mathrm{~h}$; d). CM = compact morula, BL = blastocyst, EBL = expanded blastocysts, eHBL= early hatching blastocyst, $\mathrm{HBL}=$ hatched blastocyst

Regarding Notch1, Notch2, Jagged1, Jagged2, Hes1, Sox2, Oct4, Klf4 and Cdx2 transcription, ANOVA was performed to compare the relative transcription between developmental stages, followed by LSD post-hoc analysis. Two-sided Pearson correlation coefficient was calculated to investigate the relationship between the transcription of Notch components, and between the latter and the transcription of pluripotency/differentiation markers. Chi-square test was used to evaluate the effect of Jagged1, Jagged2 and DAPT medium supplementation on in vitro cultured embryo viability and developmental rates. Results were considered significant if $p<0.05$.

\section{Supplementary information}

Supplementary information accompanies this paper at https://doi.org/10. 1186/s12861-020-00216-2.

Additional file 1: Figure S1. Boxplot of $\Delta$ Ct values of transcription levels of Notch and pluripotency and differentiation genes in $3.5 \mathrm{dpc}$ compact morulae $(n=9)$, blastocysts $(n=9)$ and expanded blastocysts $(n=7)$, and in $4.5 \mathrm{dpc}$ hatched blastocysts $(n=5)$. Ct values of target genes were normalized to the average of $\mathrm{Ct}$ of housekeeping genes Rps29 and Hprt1.

\section{Abbreviations}

ANOVA: Analysis of variance; BL: Blastocyst; cDNA: Complimentary DNA: CM: Compact morula; Ct: Threshold cycle; dpc: Days post-coitum; eHBL: Early hatching blastocyst; EBL: Expanded blastocyst; HBL: Hatched blastocyst; ICM: Inner cell mass; mRNA: Messenger RNA; NICD: Notch intra cellular domain; qRT-PCR: Quantitative real-time PCR; s.e.m.: Standard error of the mean; TE: Trophectoderm

\section{Acknowledgements}

Not applicable.

\section{Author's contributions}

MRB contributed in the conception and design of this work, acquired, analyzed and interpreted data, and was the major contributor in writing the manuscript; PD acquired data regarding embryo in vitro culture and molecular biology techniques; AT acquired data regarding embryo in vitro culture; DM acquired data regarding embryo in vitro culture; LC contributed in the conception and design of this work, analyzed and interpreted data, and was a major contributor in revising the manuscript; ES contributed in the conception and design of this work, analyzed and interpreted data, and was a major contributor in revising the manuscript. All authors have read and approved the final manuscript.

\section{Funding}

This study was supported by Project EXPL/CVT-REP/2289/2013, UID/CVT/276/ 2013 and UIDP/CVT/00276/2020 from Foundation for Science and Technology (FCT). Mariana R Batista is a fellow from FCT (SFRH-BD/90463/ 2012). Elisabete Silva is funded by FCT (DL 57/2016/CP1438/CT0001). The funding body was not involved in the design of the study and collection, analysis and interpretation of data or in writing the manuscript.

\section{Availability of data and materials}

The datasets used and/or analyzed during the current study are available from the corresponding author on reasonable request.

Ethics approval and consent to participate

All animal experimental procedures were conducted according to national and European Union legislation and approved by the national regulatory agency (DGAV - Direção Geral de Alimentação e Veterinária) and 
Institutional Animal Care and Use Committee (CEBEA - Comissão de Ética e Bem-Estar Animal; Ref. 001/2018).

\section{Consent for publication}

Not applicable.

\section{Competing interests}

The authors declare that they have no competing interests.

\section{Author details}

${ }^{1}$ Reproduction and Development Laboratory, CIISA - Centro de Investigação Interdisciplinar em Sanidade Animal, Faculdade de Medicina Veterinária, Universidade de Lisboa, 1300-477 Lisbon, Portugal. ${ }^{2}$ CBIOS - Research Centre for Biosciences and Health Technologies, Faculty of Veterinary Medicine, Lusófona University of Humanities and Technologies, Lisbon, Portugal.

Received: 17 October 2019 Accepted: 23 April 2020

Published online: 02 June 2020

\section{References}

1. Diskin MG, Morris DG. Embryonic and early foetal losses in cattle and other ruminants. Reprod Domest Anim. 2008;43(Suppl 2):260-7.

2. Jarvis GE. Early embryo mortality in natural human reproduction: What the data say [version 2; referees: 2 approved, 1 approved with reservations]. F1000Res. 2016;5:2765.

3. Rossant J, Tam PP. Blastocyst lineage formation, early embryonic asymmetries and axis patterning in the mouse. Development. 2009;136:701-13.

4. Marikawa Y, Alarcon VB. Creation of trophectoderm, the first epithelium, in mouse preimplantation development. Results Probl Cell Differ. 2012;55:165-84.

5. Strumpf D, Mao CA, Yamanaka Y, Ralston A, Chawengsaksophak K, Beck F, Rossant J. Cdx2 is required for correct cell fate specification and differentiation of trophectoderm in the mouse blastocyst. Development. 2005:132:2093-102.

6. Ralston A, Rossant J. Cdx2 acts downstream of cell polarization to cellautonomously promote trophectoderm fate in the early mouse embryo. Dev Biol. 2008;313:614-29.

7. Wei Z, Yang Y, Zhang P, Andrianakos R, Hasegawa K, Lyu J, Chen X, Bai G, Liu C, Pera M, Lu W. Klf4 interacts directly with Oct4 and Sox2 to promote reprogramming. Stem Cells. 2009;27:2969-78.

8. Schrode N, Xenopoulos P, Piliszek A, Frankenberg S, Plusa B, Hadjantonakis AK. Anatomy of a blastocyst: cell behaviors driving cell fate choice and morphogenesis in the early mouse embryo. Genesis. 2013;51:219-33.

9. Zhang Y, Yang Z, Wu J. Signaling pathways and preimplantation development of mammalian embryos. FEBS J. 2007:274:4349-59.

10. Bray SJ. Notch signaling: a simple pathway becomes complex. Nat Rev Mol Cell Biol. 2006:7:678-89.

11. Meier-Stiegen F, Schwanbeck R, Bernoth K, Martini S, Hieronymus T, Ruau D, Zenke M, Just U. Activated Notch1 target genes during embryonic cell differentiation depend on the cellular context and include lineage determinants and inhibitors. PLoS One. 2010;5:e11481.

12. Andersson ER, Sandberg R, Lendahl U. Notch signaling: simplicity in design, versatility in function. Development. 2011;138:3593-612.

13. Watanabe Y, Miyasaka KY, Kubo A, Kida YS, Nakagawa O, Hirate Y, Sasaki H, Ogura T. Notch and Hippo signaling converge on Strawberry Notch 1 (Sbno1) to synergistically activate Cdx2 during specification of the trophectoderm. Sci Rep. 2017;7(Article number):46135.

14. Cormier S, Vandormael-Pournin S, Babinet C, Cohen-Tannoudji M. Developmental expression of the notch signaling pathway genes during mouse preimplantation development. Gene Expr Patterns. 2004;4:713-7.

15. Wang QT, Piotrowska K, Ciemerych MA, Milenkovic L, Scott MP, Davis RW, Zernicka-Goetz M. A genome-wide study of gene activity reveals developmental signaling pathways in the preimplantation mouse embryo. Dev Cell. 2004;6:133-44.

16. Aghajanova L, Shen S, Rojas AM, Fisher SJ, Irwin JC, Giudice LC. Comparative transcriptome analysis of human trophectoderm and embryonic stem cellderived trophoblasts reveal key participants in early implantation. Biol Reprod. 2012;86:1-21.
17. Hosseini SM, Dufort I, Caballero J, Moulavi F, Ghanaei HR, Sirard MA Transcriptome profiling of bovine inner cell mass and trophectoderm derived from in vivo generated blastocysts. BMC Dev Biol. 2015;15:49.

18. Tang F, Barbacioru C, Nordman E, Bao S, Lee C, Wang X, Tuch BB, Heard E, Lao K, Surani MA. Deterministic and stochastic allele specific gene expression in single mouse blastomeres. PLoS One. 2011;6:e21208.

19. Deng Q, Ramsköld D, Reinius B, Sandberg R. Single-cell RNA-seq reveals dynamic, random monoallelic gene expression in mammalian cells. Science. 2014;343:193-6.

20. Guruharsha KG, Kankel MW, Artavanis-Tsakonas S. The notch signalling system: recent insights into the complexity of a conserved pathway. Nat Rev Genet. 2012;13:654-66.

21. Bray SJ. Notch signalling in context. Nat Rev Mol Cell Biol. 2016;17:722-35.

22. Alfred V, Vaccari T. Mechanisms of Non-canonical Signaling in Health and Disease: Diversity to Take Therapy up a Notch? In: Borggrefe T, Giaimo B, editors. Molecular Mechanisms of Notch Signaling. Advances in Experimental Medicine and Biology: Springer Nature; 2018. p. 187-204.

23. Andersen P, Uosaki H, Shenje LT, Kwon C. Non-canonical notch signaling: emerging role and mechanism. Trends Cell Biol. 2012;22:257-65.

24. Shi S, Stahl M, Lu L, Stanley P. Canonical notch signaling is dispensable for early cell fate specifications in mammals. Mol Cell Biol. 2005;25:9503-8.

25. Souilhol C, Cormier S, Tanigaki K, Babinet C, Cohen-Tannoudji M. RBPJkappa-dependent notch signaling is dispensable for mouse early embryonic development. Mol Cell Biol. 2006;26:4769-74.

26. Chu PW, Wang YP, Chen IC, Pan HM, Wu GJ. Notch 1 signaling pathway effect on implantation competency. Fertil Steril. 2011;96:1225-9.

27. Rayon T, Menchero S, Nieto A, Xenopoulos P, Crespo M, Cockburn K, Cañon S, Sasaki H, Hadjantonakis AK, de la Pompa JL, Rossant J, Manzanares M. Notch and hippo converge on Cdx2 to specify the trophectoderm lineage in the mouse blastocyst. Dev Cell. 2014;30:410-22.

28. Menchero S, Rollan I, Lopez-Izquierdo A, Andreu MJ, Sainz de Aja J, Kang M, Adan J, Benedito R, Rayon T, Hadjantonakis AK, Manzanares M. Transitions in cell potency during early mouse development are driven by Notch. Elife. 2019. https://doi.org/10.7554/eLife.42930.

29. Guiu J, Bergen DJ, De Pater E, Islam AB, Ayllón V, Gama-Norton L, RuizHerguido C, González J, López-Bigas N, Menendez P, Dzierzak E, Espinosa L, Bigas A. Identification of Cdca7 as a novel notch transcriptional target involved in hematopoietic stem cell emergence. J Exp Med. 2014;211:2411-23.

30. Montag $M$, Koll B, Holmes $P$, van der Ven $\mathrm{H}$. Significance of the number of embryonic cells and the state of the zona pellucida for hatching of mouse blastocysts in vitro versus in vivo. Biol Reprod. 2000;62:1738-44.

31. Sprinzak D, Lakhanpal A, Lebon L, Santat LA, Fontes ME, Anderson GA, Garcia-Ojalvo J, Elowitz MB. Cis-interactions between notch and Delta generate mutually exclusive signalling states. Nature. 2010;465:86-90.

32. Bianchi E, Sette C. Post-transcriptional control of gene expression in mouse early embryo development: a view from the tip of the iceberg. Genes. 2011 2:345-59.

33. Latham KE, Garrels JI, Chang C, Solter D. Quantitative analysis of protein synthesis in mouse embryos. I. Extensive reprogramming at the one- and two-cell stages. Development. 1991;112:921-32.

34. Bell CE, Calder MD, Watson AJ. Genomic RNA profiling and the programme controlling preimplantation mammalian development. Mol Hum Reprod. 2008;14:691-701.

35. Harvey R, Dezi V, Pizzinga M, Willis AE. Post-transcriptional control of gene expression following stress: the role of RNA-binding proteins. Biochem Soc Trans. 2017:45:1007-14.

36. Murta D, Batista M, Trindade A, Silva E, Mateus L, Duarte A, Lopes-da-Costa L. Dynamics of notch signalling in the mouse oviduct and uterus during the oestrous cycle. Reprod Fertil Dev. 2015;28:1663-78.

37. Cheng HT, Valerius MT, Surendran K, Schuster-Gossler K, Gossler A, McMahon AP, Kopan R. Notch2, but not Notch1, is required for proximal fate acquisition in the mammalian nephron. Development. 2007;134:801-11.

38. Zheng $Y$, Lin $L$, Zheng Z. TGF-alpha induces upregulation and nuclear translocation of Hes1 in glioma cell. Cell Biochem Funct. 2008;26:692-700.

39. Fischer A, Gessler M. Delta-notch--and then? Protein interactions and proposed modes of repression by Hes and hey bHLH factors. Nucleic Acids Res. 2007:35:4583-96.

40. Guo G, Huss M, Tong GQ, Wang C, Li Sun L, Clarke ND, Robson P. Resolution of cell fate decisions revealed by single-cell gene expression analysis from zygote to blastocyst. Dev Cell. 2010;18:675-85. 
41. Kared H, Adle-Biassette H, Foïs E, Masson A, Bach JF, Chatenoud L, Schneider E, Zavala F. Jagged2-expressing hematopoietic progenitors promote regulatory $T$ cell expansion in the periphery through notch signaling. Immunity. 2006:25:823-34.

42. Li D, Masiero M, Banham AH, Harris AL. The notch ligand JAGGED1 as a target for anti-tumor therapy. Front Oncol. 2014;25:254.

43. Vieira NM, Elvers I, Alexander MS, Moreira YB, Eran A, Gomes JP, Marshall JL, Karlsson EK, Verjovski-Almeida S, Lindblad-Toh K, Kunkel LM, Zatz M. Jagged 1 rescues the Duchenne muscular dystrophy phenotype. Cell. 2015;163: 1204-13.

44. Nagy A, Gertsenstein M, Vintersten $\mathrm{K}$, Behringer R. Manipulating the mouse embryo: a laboratory manual. 3rd ed. New York: Cold Spring Harbor Laboratory Press; 2003

45. Badenes M, Trindade A, Pissarra H, Lopes-da-Costa L, Duarte A. Delta-like 4/ notch signaling promotes Apc min/+ tumor initiation through angiogenic and non-angiogenic related mechanisms. BMC Cancer. 2017;17:50.

46. Livak KJ, Schmittgen TD. Analysis of relative gene expression data using real-time quantitative PCR and the 2(-Delta Delta C(T)) method. Methods. 2001;25:402-8.

47. Murta D, Batista M, Silva E, Trindade A, Henrique D, Duarte A, Lopes-daCosta L. Dynamics of notch pathway expression during mouse testis postnatal development and along the spermatogenic cycle. PLoS One. 2013;8: e72767.

\section{Publisher's Note}

Springer Nature remains neutral with regard to jurisdictional claims in published maps and institutional affiliations.

Ready to submit your research? Choose BMC and benefit from:

- fast, convenient online submission

- thorough peer review by experienced researchers in your field

- rapid publication on acceptance

- support for research data, including large and complex data types

- gold Open Access which fosters wider collaboration and increased citations

- maximum visibility for your research: over $100 \mathrm{M}$ website views per year

At BMC, research is always in progress.

Learn more biomedcentral.com/submissions 